(2018), 1 (1): 36-47

\title{
AN ANALYSIS OF MORAL VALUES OF THE RAINBOW TROOPS NOVEL BY ANDREA HIRATA
}

\author{
Lonasari Afandi \\ lonasariafandi@gmail.com \\ IKIP Budi Utomo Malang
}

\begin{abstract}
This research was conducted to describe the moral values based on the Novel Rainbow Troops. In conducting this research, the researcher used a descriptive qualitative method. The objective of the study are to find the moral values in Rainbow Troops novel. The method used in this study was document study. In this study, the researcher collected the data of the research dealing with the primary data source, using documentation. The findings of the moral values that were found in the novel are Individual Moral such as Discipline, Social Moral such as, Tolerance and Mutual Help, Religious Moral such as, Religious Education, Faith and Ethics, Cultural Moral and Educational Moral. The result of this research was expected to give additional information to reader and contribute to the development of literary study particularly among students who are interested in the literary study. Therefore, this study of reading novel or other books to make meaning, enjoy with learning process. It becomes one of alternative way to improve moral crisis in our life.
\end{abstract}

Key words: Moral Values, Literary Element, Literature Explanation

CPendidikan Bahasa Inggris FPISH IKIP BU Malang

\section{INTRODUCTION}

Language is a system of conventional spoken, manual, or written symbols by means of which human beings, as members of a social group and participants in its culture express themselves. Language is used to communicate with others in order they get information they need to know. People and language cannot be separated to get the information because language becomes the primer media of communication. According to Wibowo language is a system of symbols that are meaningful and articulate sound (generated by said tool) which are arbitrary and conventional, which is used as a means of communicating by a group of human beings to give birth to feelings and thoughts (Wibowo, 2001: 3).

To get the new information and to convey the science and technology, most people in the world do an activity such as reading. Some people like reading to spend their time. There are five main purposes for reading. For examples; reading for getting specific information, application, pleasure or entertainment, ideas, and reading for understanding. Based on the reasons, actually human wants to get the advantages of information given in the text, in getting moral values information, we can also get it in literature text, such as novel.

People use language to express their ideas, opinion, feeling and thoughts. Moreover, language as a media of communication can create a literary work. Literature is a social institution and it cannot be separated from the society. Literature is the product of an author who is a member of the society. There are five genres of literature, such as, poetry, drama, prose, nonfiction, and media.

Since long time ago, literature has become elements of human life and society in which literature exists; it has given much entertainment and biggest inspiration. Literature is a kind of information we need. Literature includes 
forms of writing which deliberately and creatively experiment with language in order to suggest images and ideas which engage the reader's imagination (Goodman, 2001: 5). By reading literature, we will discover ourselves and our world, expressing the fact and imagination as a human life manifestation with language as medium and has a positive effect of human life (humanity). According to Burton (2014), literature isn't really easy to define in an absolute sense but to him it includes works that masterfully present the human condition and expands our understanding of the very essence of humanity. Our motivations, our fears, our love our failings, our potential forgreatness, the depths of suffering, the power of redemption. Literature has the power to change him, to make him more than he was. To make him different in some capacity. To allow him to go out into the world and better understand all the grey areas of human existence.

Some literary works become so popular that they are well known all over the world because of their critical thinking about society phenomenon. Novels can be one of the various texts of literary works. According to Diyanni (2004), in reading fiction such as novel we share the imaginative vision of another, adopting, however briefly, his or her way of perceiving the world. There is certain message in the novel, such as moral, because reading novels is also learning about life in a surprising way without taking any risks, we take apart in the action of story and authors.

In this global era, we need to improve our moral values in order not get bad influences. Discussing about moral Robert Frost define it as the standards by which we define right and wrong. They can come from the self, family, community, religion, government, or any other entity that influences the thoughts of the individual. Every action, attitude, responsibility, good conduct, and ethics of human will reflect the moral value. Moral can evaluate with the actions and potential actions of others, may be evaluated as good or bad; right or wrong; morally acceptable or unacceptable (immoral); morally required, prohibited, or permitted; morally praiseworthy or blameworthy.

Those moral sometimes are reflected in some literary work such as novels. Therefore, novels do play important roles in daily life. They can function as social critiques, entertains as well as delivery moral. As novel plays roles in social life, many studies have been carried out to analysis this literary work.

There are two previous studies dealing with novel analysis which the writer personally takes into account. The first study was done by the student of State Islamic Studies Institute (STAIN) Salatiga, Dani Atik Susanti (2012), entitled "An Analysis of Moral Values taken from Edensor Novel by Andrea Hirata". The study was aimed to find the literary elements in Edensor novel, to find the moral values in the novel, to find the way of presenting the moral values in the novel, and to find the implication of moral values in Edensor novel in education. The method used in this study was document study as the technique of collecting the data. In the study, the researcher collected the data of the research dealing with the primary data source. The results of finding the literary elements were divided into five parts; those are character and characterization (major and minor character), plot (exposition, conflict, climax and resolution), setting (place and time), theme, and point of view. Moral values found in the novel as never 
give up, nationalism, empathy to each others, strength of heart, optimism and thinking positively, believe in God, there is no reason to stop learning, struggle for life. In presenting the moral values the author uses explicit, implicit meaning and using imagination. The implication of moral education of the novel is that we can take moral values of the novel as education for us and takes them as guidance and improve our moral.

The second one is the thesis entitled "An Analysis of Moral Values in Ahmad Fuadi's Novel Rantau 1 Muara" written by Anis Kusmiyati, Wijaya Putra, University, 2014. This research is intended to describe the moral values based on the main character. In the other word is to describe the morality of the main character to stem from individual moral, social moral, and religion moral. The researcher used a descriptive qualitative method with data analysis approach. In this research the researcher used the theory of moral/moral message by Burhan Nurgiyantoro Teori Pengkajian Fiksi. In literary work, moral generally means some suggestion that related with tenet of practical moral values, that can be understands by the readers through the text story. The moral tenet itself included problems of human life. Generally the problems of human life can be divided into three parts interaction such as: interactions between human to themselves or the person to him/herself, human to others and environment, and the interaction between human to their God. From this study the researcher found three kinds of moral values, there are some of the kinds of moral values: (1) Interactions of the human to themselves is called individual moral, such as: discipline, confidence, self-respect and bravery, responsibility and independence, patience, consistency, hard worker and optimism.
Interactions of the human to others and environment is called social moral, such as: solidarity to others, care to others, help each other, and love to others. (3) Interactions of the human to their God is called religion moral, such as: syukur/thanks to God, dzikir/remember to Allah, tawakal/trust in God who orders everything, doa/pray to Allah, and obedient to Allah and His messenger.

Of the two novel analysis, we can see the difference where the first novel analysis focused on moral values but it expand the review on education. And the second one, just analyzed the moral values in its only element review. The both novel analysis mentioned above do not include literature as the main theory consideration review. Therefore, the researcher discusses and includes the main literature explanation which in turn leads toward moral values and education.

The researcher was interested in novel as literary work because she wanted to make readers realize that there are many problems in life and there are always good ways to overcome them. The researcher, in this chapter emphasizes on how the main character follows the moral value to create a good motivation in life.

In this study, the researcher would like to please the reader by the messages that can be found in novels suggested for moral values. Many people like reading the novels, for examples Andrea Hirata's novel such as Edensor, The Dreamer (Sang Pemimpi) and many others. Now, the researcher would like to analyze moral values in one of the novels, namely The Rainbow Troops (Laskar Pelangi). It is not merely an art or stroy novel but also a political, economic, culture, ethic, and language. It is absolutely right to call this book as 
inspiration novel about moral values and education.

The researcher chose this novel because the novel that tells the story of the lives of poor school students with the beauty of Belitung Island was awarded ITB Buch Award 2013 in the world's largest tourism exhibition, ITB Berlin, which was taking place at the Messe Berlin building on March 8, 2013. The novel of Rainbow Troops written by Andrea Hirata published by Bentang Pustaka, Yogyakarta it contains 465 pages has become best seller since it has been published in the year of 2009 and won the title "International Best Seller" in Turkey. In addition to the award was obtained ie, The Winner of BuchAwards Jerman 2013, the Winner of the festival Book New York 2013 (general fiction category), and Honorary Doctor of Letters (Hon DLitt) from Warwick university 2015. Rainbow Troops phenomenal book work of Andrea Hirata re-carve achievements when appointed to the big screen. In the Indonesian Movie Award 2009 which aired RCTI on Saturday, May 16, 2009, this film bought some awards. Finally, Rainbow Troops film became the best film in Indonesian Movie Award 2009.

\section{RESEARCH METHOD}

\section{Research Design}

To answer the research problem, the descriptive qualitative use to analyze the moral values of the rainbow troops novel by Andrea Hirata. Based on web (www.qrca.org), qualitative research is designed to reveal a target audience's range of behavior and the perceptions that drive it with reference to specific topics or issues. It uses in-depth studies of small groups of people to guide and support the construction of hypotheses.
The results of qualitative research are descriptive rather than predictive.

There are five characteristics of qualitative approach according Biklen in (Moleong, 2002:27-29). First, it has natural setting the direct language data source and the researcher are the key instrument. Second, the data obtained are in the form of word not in statistic one. Third, the processes are more importance than the result. Forth, the data are analyzed inductively, the researcher analyze from the general and conclude into specific aspect. Fifth, qualitative approach is participant perspective.

The researcher used a descriptive qualitative research, which is defined as a research of which the data in the form of written or oral words that is descriptively analyzed. Qualitative research deals with a kind of research which doesn't use statistic procedures in analyzing the data. In a descriptive qualitative research, the researcher tends to prior in accurate explanation to analyze and present what have been found.

Qualitative research includes the descriptive research, in which most of the data were collected in the forms of words. The research contained quotation from the data of documents to illustrate the presentation. Usually, it describes the world in narrative form. The researcher used a descriptive research in order to describe the moral values in "Rainbow Troops" novel by Andrea Hirata.

In this reseach, the reasearcher made a research plan and arranged it in certain procedure as guidance in doing her research. This is a library research, so the writer used descriptive- qualitative research methods. This method was chosen because literature, as the object of this research, is a form of creative 
work which can be interpreted in universal way.

The following methods used for the current study were:

1. Theoretical literature analysis was used to provide some theoretical background to the problem.

2. The descriptive method was used to define, explain, and clarify the moral values of the Rainbow Troops novel by Andrea Hirata.

3. The figure of word, figure of though and figure of...analysis were used to identify the moral values of the Rainbow Troops novel by Andrea Hirata.

\section{Research Object}

The research objects in this study is moral value existed in the novel of Rainbow Troops written by Andrea Hirata published by Bentang Pustaka, Yogyakarta. It contains 465 pages. This novel has become best seller since it has been published in the year of 2009 .

Data and Source data

Data are vitally essential for conducting research. They were analyzed according to the proper descriptive, narrative, and interpretive approach in this study. Source of data must also be included because it will give a clear idea on how the data analyzed and relevant with the appropriate problem (Tanzeh, 2014: 25). The supporting data are in the form of related references (field not review) that was taken from relevant books, theories, materials about moral values. The data that would be used here was 48 chapters (465 pages) in Rainbow Troop novel by Andrea Hirata. The data needed in this research were all in reference to expressions, phrases and statements related to moral values in the novel. The Primary data were collected from the novel "Rainbow Troops" written by Andrea Hirata. The source of data comes from the novel itself which was published in December 2009 by Bentang Pustaka.

Research Instrument

In terms of qualitative research instruments, Lincoln and Guba in Sugiyono (2006) states that the instrument of choice in naturalistic inquiry is the human (the current researcher).

In addition, Nasution in Sugiyono (2006) states in qualitative research, there is no other choice than to make human beings as the main research instrument. The instrument (human) was aimed to decide research problem, research focus, research procedures, hypoteses used, even expected result which can not be determined definitely and clearly beforehand.

In the description of the previous study, it has also been mentioned that as an object of interest (gaze) in obtaining information, the researcher paid attention to the kinds of sources; writings, places and papers. Therefore, they would lead the researcher to the next instrument; documents (novel rainbow troops by Andrea Hirata and other related references) In terms of documents Bogdan in Sugiyono (2006) states in most tradition of qualitative research the phrase personal document is use broadly to refer to any first person narrative produced by an individual which discribes his or her own actions, experience, and belief.

\section{Data Collection}

The procedures of collecting the data were important. They were intended to know how the data collected and 
answered according to the questions to the research problem. The researcher has to decide and choose the right procedures to collect the data.

Process of collecting data in this research was all done through the library search and literature scheme. The data were collected from library in few places where the books related to this research were available to get more precise information or support in the research process. It is the most common method in doing a research dealing with literary works. Library research is done to collect, identify, define, evaluate, and describe the data of the story. To complete the data and enough information, the researcher used the library as supporting the data. The researcher read the novel in order to get a deep comprehension about moral values and its application in English language teaching. Then the information that was considered to be important and related to the topics was recorded in a piece of paper. And the last, the researcher drew the conclusion and analysis. The researcher only took the relevant data which support the topic discussed in this thesis.

The researcher would use some steps in order to find relevant information that had been checked. The process of finding data began with finding references from general into specific information, which can be presented in steps as follows:

1. Visiting library to find relevant articles, books and biographies and to get more detailed information that is related to issues to be discussed by the researcher as a supporter in research.

2. Choosing the description of important material related to moral values of the main characters from provided source
3. Reading repeatedly the Rainbow Troops novel written by Andrea Hirata. The first reading, to know the general description of the content of the Rainbow Troops novel. The second, to identify and mark sentences containing moral values. The third, to ensure the sentences that have been identified and marked.

4. Recording all information into interpretive narrative field note references review.

5. Classifying data that includes moral value.

Data Analysis

Miles and Huberman in Sugiyono said "the activity of analyzing the data for qualitative was done by interactive and continued until finished. To analyze data, the researcher used descriptive analysis the activity in analyzing data were as followings:

1. Identifying the researcher identified sentence phrases that showed moral value, it was identified by read repeatedly to find or confirm sentences that showed the moral value

2. Coding the researcher did the encoding by used the alphabet letters and numbers to classify the moral values contained in the novel. The first group for the alphabet letters showed a kind of moral values such as, $\mathrm{D}$ for discipline, $\mathrm{R}$ for religious, $\mathrm{E}$ for education and $\mathrm{C}$ for culture. The second used numbers to show a page and paragraphs of the moral values.

3. Data Reduction was focused on the important data and finding theme, and eliminating the data that was not important. Therefore, the data reduction would give clearer description so that researcher would be easily found the data needed. In this data reduction, the researcher only focused this research on 
moral values in Andrea Hirata's novel by title "Rainbow Troops".

4. Data Display was the next step after data reduction. In qualitative approach, data display would be done in short essay. Miles and Huberman state that. "The most frequent form of displaying data for qualitative research data in the past has been narrative text".

5. Data Interpretation The basis of discourse analysis was interpretation, because sentence analysis is part of the interpretive method. So in analyzing the data at this stage the researcher in addition paid attention to the script in the novel rainbow troops that contained the moral message formed, for the next step researcher would interpreted it.

6. Triangulation in data collection was aimed to check the validity of the data researcher used. Triangulation is defined as a technique that combines various existing technique. Susan Stainback in Sugiyono (2006) stated that the aim was not to determine the truth about some social phenomenon, rather the purpose of triangulation is to increase one's understanding of what ever is being investigated. The purpose of triangulation was not to seek the truth about some phenomenon, but rather on increasing the researcher understanding of what had been found. Denzin (in Moloeng 2004), distinguished four kinds of triangulation, among others by make use of resources, methods, investigators and theoris. In this study, of the four kinds of triangulation, to get this study more reliable, the researcher rechecked her data using investigated officer, they were the advisor of this study, and one a lecturer. They were both competent and professionally an expert in literature. They also have competence in english language proficiency, which influential for this study and seen as the necessary in language literature analysis that is
Moral values in Rainbow Troops novel by Andrea Hirata. The validators are:

1. Sri fatmaning H., S.S, M.Pd as advisor also as English Education lecturer of IKIP Budi Utomo Malang 2. Trisnian Ifianti M.Pd as English lecturer of IKIP Budi Utomo Malang

Based on the results of data analysis as a whole the moral values in the Rainbow Troops Novel were divided into individual, social, religious, culture, and education moral. The moral values were obtained by looking at the process of conversation / dialogue and the role of the characters in the Rainbow Troops novel. The findings of the authors based on the presentation of the results of data analysis will be described below in accordance with the systematic discussion of all aspects.

In previous findings were comparison with the findings of the current. Where the previous findings there are only three moral values as follows; Individual Moral, Social Moral and Religious Moral. While the present study was found five moral values as follows:

\section{Educational Moral}

Moral education is a planned undertaking to change attitudes, behaviors, actions, behaviors undertaken by learners to be able to interact with the community environment in accordance with the moral and cultural values of local communities. On the other hand, according to Alfian Muhammad (2013) stated that moral education is an effort to equip learners through the activities of guidance, teaching and training during the growth and development itself as a provision for the future, in order to have a clean conscience, behave well, and maintain morality in performing 
obligations to God and To the fellow creatures, so as to form a whole person which is reflected in the behavior of speech, deeds, attitudes, thoughts, feelings, work and work based on religious values and noble norms and morals of the nation. The goal is to form a child's person, to be a good human being, a citizen, and a good citizen. As for good human criteria, good citizens, and good citizens for a society or nation, in general are certain social values, which are heavily influenced by the culture of society and nation.

Thus moral education can be likened to the term ethical education, character education, value education (education moral) or affective education. There is also by using the term character education and moral education In this case the terms can replace each other. So this term can not be separated from the understanding of morals, values, character, character, affective itself.

According to the script of Education curriculum of Budi Pekerti issued by Puskur Depdiknas (2001) states that the understanding of moral education can be reviewed conceptually and operationally.

The conceptual definition of character education includes the following matters:

A conscious effort to prepare learners to be complete human beings of virtuous character in all their present and future roles.

Efforts to establish, develop, improve, maintain and improve the behavior of learners so that they are willing and able to carry out their life tasks in harmony, harmonious, balanced (inner birth, spiritual material and individual social).

Educational efforts to form learners into a whole person of virtuous noble character through guidance, habituation, teaching and training, and exemplary.

The understanding of character education is operationally an effort to equip learners through the activities of guidance, teaching and training during the growth and development itself as a provision for the future, in order to have a clean conscience, behave well, and maintain morality in performing obligations to God and To the fellow creatures, so as to form a whole person which is reflected in the behavior of speech, deeds, attitudes, thoughts, feelings, work and work based on religious values and noble norms and morals of the nation.

\section{Religious Moral}

Religious in a literary work is one of the problems that can not be separated from the literary work. As one of the literary genre, the novel comes in a very complex social environment; of course, the literary work carries a religious or religious moral that is a representation of the author's social life. Religious in its sense can be grouped into two parts, namely religious according to language and religious by term. According religious language comes from Sangsekerta language which is closely related to Hinduism and Buddhism which means " not go "remain in place, inherited from generation to generation.

According to the term religious is a law or rules that bind man in relation to his god and human relationships with fellow human and human relationships with nature.

Man has limited ability, awareness, and acknowledgment of his limitations to make the belief that there is something extraordinary beyond him. Something out of the ordinary comes from a remarkable source as well. And 
the extraordinary sources are varied according to their own human language such as God or god.

In accordance with the definition above, the moral value in the context of religious is an important problem to be conveyed by the author as one of the mandate to add Khasana conception of the epistemology of the reader about human relationships with humans, human beings with the environment, human beings with themselves, and people with god.

\section{Cultural Moral}

In addition to religious elements, literature is also closely related to culture in the study culture literature is a representation of the culture so that its existence is very difficult to separate from each other.

Culture can essentially be divided into the first two parts, a culture that is capable of being seen, perceived by the use of the five senses and the second, constitutes an accumulation of knowledge, belief, art, morals, law, customs, and other traditions, The result of human reason. According to E.B. Taylor, Culture is a complex whole that includes beliefs, morals, art, customs, laws, abilities and other habits that are oft Journal of English Language and Pedagogy socicty.

Culture can also be interpreted as something that will affect the level of knowledge and include the system of ideas or ideas contained in the human mind, so that in everyday life, the culture is abstract.

Novel is one of the literary genres as a media of cultural actualization that represents a particular society or community culture. Therefore, culture is one element that is always present in a literary work.
The culture essence in the novel was clearly showed in the habit, tradition and the way the writer discribe each character in the novel.

\section{Social Moral}

According Uzey (2009) stated that social moral refers to the consideration of the act objects; a way to make decisions is something worth it has the truth, the beauty and the value of the divine. Human is individual and social personal, the human certainly doing interactions with others in life. In the finding of the novel the social moral There are two contents of the first tolerance and the second one mutual help. According Kemendiknas (2010) tolerance is attitude and actions appreciate the difference of religion, parts, ethnic, opinion, attitudes, and actions others different from himself and mutual help is action showing pleasure to speak, hang out, and work with others. Both such content include social morals as it refers to the standard goods or bad behaviors in society in order to make the relationship to be close and respect each others.

\section{Individual Moral}

In previous study Anis Kusmiyati (JOURNEY) (2018), 1 (1): 23-28 of svivial v alues ill Mimliau i uaus s ivuvel Rantau 1 Muara" stated that individual moral is the attitude of the human to him/herself, its means that human has the right to make their decisions and a spirit to do something or actions. For the example in the finding there is a discipline. Discipline is behavioral patterns that are expected to produce certain characters, in particular resulting in a more orderly moral and mental improvement. According Kemendiknas (2010) stated that discipline is actions that show the behavior of the orderly and 
obedient various terms and rules. Therefore, discipline includes the moral of the individual because of his selfpriority. Everybody needs the individual moral, individual moral support human to reach happiness and perfectly life as personality through used all the potency, ability, and soft skill. Finally individual moral are very important things to walk of life.

\section{CONCLUSION AND SUGGESTION}

In this chapter the researcher is going to draw a conclusion about moral values that expressed in Andrea Hirata's novel Rainbow Troops. From this analysis the writer found five kinds of moral values. The first is the actions of main character to himself, as individual moral. The second is the actions of main character to his environment, in this case includes the action of main character to the people around him, like the family and friends, as social moral. The third is about the actions of main character to his God or the main character religion, as religion moral. The fourth is about the actions of main character to his knowledge, belief, art, morals, law, customs and other tradition, as cultural moral. The fifth is about the main character to his science. Provide guidance and material about science, as educational moral.

After analyzing the kinds of moral values, the writer found some contents of each moral. For the first is about Individual Morals are discipline. The second is about Social Morals the contains are the power of friendship and mutual help. The third is about Religion Moral the contains are religious, faith and ethics. The fourth and fifth there is no contains because in the quotation of the sentence has been described about how culture and education in Belitong.
Based on the statement above, the contents of the novel is more dominant to good moral values. It contains about the morality of main character that has good attitude to all of people around him. He is very good as the individual and social personal, he has the attitude that can conform in many situations and conditions. We can take some kinds of morals in this novel as a role of our life. It is a wonderful way to improve our behavior and develop our intelligent spiritual.

\section{Suggestion}

Based on the explanations above, the writer would like to give suggestions for the students, english teachers and the further researchers. For the students, this study is expected to enrich knowledge about value of life that very important things for our life. So enrich your knowledge by reading science books and reads of many literary books, especially novel. For english teachers being a source of material or conception for teachers to be a guide in learning english literature is interesting, creative and innovative. For the further researchers, it is hoped that the study of moral value in the Andrea Hirata's novel Rainbow Troops can be inspired continuing research in different novel by similar study.

\section{REFERENCES}

Arifin, Zainal. 2014. Penelitian Pendidikan. Bandung : PT. Remaja Rosdakarya

Arikunto, Suharsimi. 2013. Prosedur Penelitian : Suatu Pendekatan Praktek, Cetakan Kelimabelas. Jakarta : Rineka Cipta

Burhan, Bungin. 2011. Penelitian Kualitatif Komunikasi : ekonomi, 
Kebijakan Publik, dan Ilmu Sosial Lainnya, Edisi Kedua. Jakarta : Kencana

Burton, Jeremy. 2014. Read Literature. (https://www.quora.com/, Downloaded on $07^{\text {th }}$ May 2017)

Di Yanni, Robert. 2004. Literature Approaches to Fiction, Poetry and Drama. Mc Graw Hill : New York

Dictionary.2017.Examplesof Morals. (http://examples.yourdictionary.c om.examplesofmorals)

Drucker, Haley. 2017. Brightub Education. (http://genresofliterature.com//

Esterberg, Kristin G., 2002. Qualitaive Methods in Social Research. New York : Mc. Graw Hill.

Goodman, Lizabeth. 2001. Literature and Gender. London : The Open University

Harianti, Dra. Diah, M.Psi. 2011. Kementerian Pendidikan Nasional Badan Penelitian dan Pengembangan Pusat Kurikulum dan Pengembangan Pusat Kurikulum dan Perbukuan Jakarta, 2011. Panduan Pelaksanaan Pendidikan Karakter di Satuan Pendidikan,Kemendiknas2011.(R epository.unand.ac.id/22742/1/4_ panduan.pelaks_pendidikan_kara kter.pdf) Download on $04^{\text {th }}$ August 2017

Hirata, Andrea. 2005. Laskar Pelangi. Yogyakarta: PT. Bentang Pustaka.
Hirata, Andrea. 2009. The Rainbow Troops.Yogyakarta : PT. Bentang Pustaka

Hirata, Andrea. 2011. Edensor. Yogyakarta: PT. Bentang Pustaka.

Hornby, A S. 2015. Oxford Advanced Learner's Dicitionary of Current ent English $\left(7^{\text {th }} e d\right)$. Oxford New York : Oxford University Press

IKIP Budi Utomo. 2015. Pedoman Penulisan Tugas Akhir. Malang: Pusat Penelitian dan Pengabdian Masyarakat (P2M)

Iyar, Nikita. 2008. "Educational Values, Meaning, Objectives and Source, Article". (Schoolash.

Blogspot.co.id. www.qrca.org Download on $7^{\text {th }}$ May 2017)

Kusmiyati, Anis. 2014. An Analysis of Moral Values in Ahmad Fuadi's Novel Rantau 1 Muara. Un Published Thesis, Wijaya Putra University.

Margono, S. 2010. Metode Penelitian Pendidikan. Jakarta : Rineka Cipta

Moloeng, Lexy J. 2002. Metode Penelitian Kualitatif. Bandung : Rosda

Moloeng, Lexy J. 2014. Metode Penelitian Kualitatif. Bandung : Rosda

Mukhlich, KS. 2006. Konsep Moral dan Pendidikan Dalam Manuskrip Keraton Yogyakarta. UIN Sunan kalijaga : Yogyakarta. 
Nurgiyantoro, Burhan. 2000. Teori Pengkajian Fiksi. Yogyakarta : Gajah Mada Universitas Press.

Pusat Kurikulum, Jakarta. 2010. Pusat Kurikulum Pengembangan Pendidikan Budaya dan Karakter.(http://gurupembaharu.c om/home/wpcontent/uploads/do wnloads/2011/11/PanduanPenerapan-Pendidikan-KarakterBangsa.pdf ) Download on $04^{\text {th }}$ August 2017

Ratna, Kutha Nyoman. 2013. Teori, Metode, dan Teknik Penelitian Sastra dari Strukturalisme hingga Postrukturalisme perspektif Wacana Naratif. Yogyakarta: Pustaka Pelajar

Risdiyanto, Faizal, S.S,M.Hum. 2011. Intoduction to Literature. Yogyakarta : Trust Media

Robert, Frost. 2014. Moral Values in Education.

(https://www.quora.com/, Instructor and Flight Controller at NASA, Download on $07^{\text {th }}$ May 2017)

Subhan, M.S, Bustami. 2003. A Guide to Literary Criticism. Yogyakarta : Debut Press

Sugiyono, Dr. 2014. Metode Penelitian Kuantitatif, Kualitatif dan $R \& D$. Bandung : Alfabeta

Susanti, Dani A. 2012. An Analysis of Moral Values taken from Edensor Novel by Andrea Hirata. Un Published Thesis, STAIN Salatiga. 